\title{
Effect of Platelet-rich Plasma on Caspase-3 and IGF-1 mRNA expression in the diabetic rat testis.
}

\author{
Evi Istiqamah1,4, Dicky Moch. Rizal ${ }^{2}$, Ika Puspitasari3
}

1. Postgraduate Student of Master Biomedical Science, Faculty of Medicine, Public Health and Nursing, Universitas Gadjah Mada, Yogyakarta, 55281 Indonesia

2. Department of Physiology, Faculty of Medicine, Public Health and Nursing, Universitas Gadjah Mada, Yogyakarta, 55281, Indonesia

3. Department of Pharmacology and Clinical Pharmacy, Faculty of Pharmacy, Universitas Gadjah Mada, Yogyakarta, 55281, Indonesia

4. Department of Midwifery, Faculty of Public Health, Universitas Muslim Indonesia Makassar, Jl Urip Sumoharjo KM. 5, Makassar Sulawesi Selatan 90231 Indonesia

\begin{tabular}{l}
\hline Info Article \\
Submitted: $13-02-2019$ \\
Revised: $09-04-2019$ \\
Accepted: $29-04-2019$
\end{tabular}

*Corresponding author Dicky Moch Rizal

Email: dickymd@yahoo.com

\begin{abstract}
Testicular damage is a serious complication of diabetes mellitus resulting in male infertility, which is associated with caspase-3 and IGF-1 mRNA expression. Platelet-rich plasma (PRP), with its rich growth factor composition, has proven beneficial in regenerative therapy. It is believed that PRP has not been studied in testes for complication of diabetes mellitus and there are no studies in the literature concerning the influence of PRP on expressions of growth factors in diabetic rat testis. The aim of this study was to investigate the efficacy of adjunctive PRP in insulin treatment for repair of testicular damage in a diabetic rat model. Diabetes was induced by administering single dose $60 \mathrm{mg} / \mathrm{kg}$ streptozotocin. Twenty Wistar male rats were divided into four groups: group 1, control group; group 2, diabetes without treatment; group 3, diabetes with treated insulin; and group 4, diabetes with treated insulin and PRP. Rats were euthanized after two weeks of treatment, and testes were taken for caspase-3 and IGF-1 mRNA expression measurements. Diabetes mellitus induction caused a significant increase in caspase-3 mRNA expression with $p=0.049$ and significant decrease in IGF-1 mRNA expression with $p=0.004$. There was no difference in caspase-3 and IGF-1 mRNA expression of the diabetic rat testis given insulin and PRP compared to without PRP.
\end{abstract}

Key words: PRP, diabetic rat testis, caspase- 3 mRNA expression, IGF-1 mRNA expression.

\section{INTRODUCTION}

Male reproductive system damage due to diabetes mellitus (DM) is a disorder that results in a decrease in male fertility (Kianifard et al., 2012; Shi et al., 2017; Sisman et al., 2014). Testicular damage due to DM is damage that occurs other than the pancreas (Sisman et al., 2014). A molecular mechanism in the form of oxidative stress and apoptosis causes testicular damage (Shi et al., 2017). Information about the mechanism of damage caused by DM through oxidative stress and apoptosis is the reason for further research, namely study on substances that can prevent oxidative stress and apoptosis and aid in repairing testicular damage due to DM. The increase in caspase-3 is a link between oxidative stress and apoptosis. The increase in caspase- 3 in the testes becomes a measure of testicular damage and a decrease in caspase- 3 is an indicator of the success of therapy (Morsy et al., 2014; Shi et al., 2017).

Research related to growth factors in DM testicles via streptozotocin (STZ) induction shows a decrease in vascular endothelial growth factor (VEGF) (Sisman et al., 2014) and insulin like growth factor-I (IGF-1) (Olchosky et al., 1991). IGF-1 deficiency in the testis can damage the testes so that they cannot function (Castilla-Cortázar et al., 2015; Puche and Castilla-Cortázar, 2012). 
Provision of Platelet-Rich Plasma (PRP) causes an increase in IGF-1. Increased IGF-1 after administration of PRP was found in rat tendons and human serum (Lyras et al., 2010; Wasterlain et al., 2013). IGF-1 was found to be higher in PRP compared with IGF-1 in whole blood. IGF-1 found in PRP has a major role in tissue repair (Dhillon et al., 2012). The role of IGF-1 can overcome testicular damage, based on the improvement of testicular damage after administration of IGF-1 (Castilla-Cortázar et al., 2015). Research using IGF1 in testicular cells concluded that IGF-1 can prevent apoptosis in germinal cells (Ozkurkcugil et al., 2004) and Leydig cells (Wang and Hardy, 2004; Yoon and Roser, 2010). This study aimed to investigate the efficacy of adjunctive PRP in insulin treatment for repair of testicular damage in a diabetic rat model by assessing caspase- 3 and IGF1 mRNA expression.

\section{MATERIAL AND METHODS}

The study was approved by the Medical and Health Research Ethics Committee of FK-KMK UGM, Yogyakarta, Indonesia (Permission number: KE/FK/1056/EC/2018). Twenty Wistar male rats (Rattus norvegicus) were obtained from the Department of Pharmacology and Therapy FKKMK UGM (Yogyakarta, Indonesia). The rats were 8 weeks old and their mean weight was $210 \pm 60 \mathrm{~g}$. The rats were maintained in spacious cages and were given food and water ad libitum. The animal room was ventilated and was under a 12h/12h light-dark schedule.

Four study groups were formed randomly: Group 1: The control group (Control): Rats that received single i.p injections an equal volume of NaCL 0.9\%; Group 2: The diabetes without treatment group (DM-0): Rats that received a single i.p injection of STZ in a dose of $60 \mathrm{mg} / \mathrm{kg} \mathrm{BW}$ for induction of diabetes. After $72 \mathrm{~h}$ (considered day 0) of STZ injection, blood samples were collected from the retroorbital vein and glucose levels were measured. Individual glucose levels that reached above $300 \mathrm{mg} / \mathrm{dL}$ were considered diabetic; Group 3: The diabetes with insulin group $(\mathrm{DM}+\mathrm{I})$ : Rats that received a single i.p injection of STZ in a dose same time and dose as the DM-0 group; after 3 weeks 3 days with confirmation of the induction of the diabetes, rats received Lantus ${ }^{\circledR}$ (insulin glargine) in a dose of 0.9 Unit/100mg BW by subcutaneous (SC) injection every day for 2 weeks; Group 4: The diabetes with PRP and insulin group (DM+I-PRP): Rats that received a single i.p injection of STZ in a dose same time and dose as the DM-0 group; Rats received a subcutaneous (SC) injection of Lantus $^{\circledR}$ (insulin glargine) in the same time and dose as the DM+I group. Rats received PRP in a dose of $0.1 \mathrm{~mL}$ (Platelet $>1.000 .000 / \mu \mathrm{L}$ ) by subscrotal injection three times for 2 weeks.

\section{Preparation of Platelet-rich plasma}

For the preparation of PRP, $10 \mathrm{~mL}$ of fresh venous blood with $1.4 \mathrm{~mL}$ citrate buffer (anticoagulant) were collected into a single syringe from an antebrachial vein under aseptic conditions. The blood was subjected to double centrifugation methods (Prosys PRP, Prodizen Inc), and in the first centrifugation the tubes were centrifuged at 1200 revolutions per minute (rpm) for $10 \mathrm{~min}$. This resulted in 3 different density compartments; the inferior layer containing red blood cells, the intermediate layer containing buffy coat of white blood cells, and the superior layer containing plasma. The plasma containing platelets was protected from red blood cells by being connected to empty syringes. An empty syringe in the side position was set with the connector above the syringe containing plasma in a vertical position. The plasma was centrifuged again at $3500 \mathrm{rpm}$ for $10 \mathrm{~min}$. This procedure resulted in the production of platelet-rich plasma (PRP). Platelets were counted using an automated hematology analyzer (Sysmex KX 21, Yuesen Med). Platelet counts $>1.000 .000 / \mu \mathrm{L}$ were used.

\section{Euthanasia}

After final weight measurements and blood samples were collected for glucose measurements (by GOD PAP kit), the rats were euthanized (by decapitation). After testis sample collection for analysis, the rats were cremated through incineration in an appropriate environment.

\section{Total RNA extraction and cDNA synthesis}

The total RNA from the testicular tissue was isolated using the TRI-RNA reagents (Favorgen, Taiwan). The concentrations of RNA were determined by NanoVue Plus spectrophotometer (GE Healthcare, USA). Total RNA was extracted from testes of the rats.

The integrity of RNA samples was verified by measuring the ratio of ODs at $260 \mathrm{~nm}$ and $280 \mathrm{~nm}$. Only the RNA samples that had a ratio $>1.8$ were used for the subsequent cDNA synthesis. The first-strand cDNA was synthesized from RNA using cDNA synthesis kit (Smobio, Taiwan) according to manufacturer's instructions. 
Table I. The mean and standard deviation of rats' weight and blood glucose levels after 2 weeks of insulin and PRP administration. The significant difference between the two groups was determined by ANOVA followed by LSD post hoc.

\begin{tabular}{lllll}
\hline & Control & DM-0 & DM+I & DM+I-PRP \\
\hline $\begin{array}{l}\text { Last weight (g) } \\
\text { Blood glucose } \\
\text { level (mg/dL) }\end{array}$ & $839.80 \pm 13.51(5)$ & $173.80 \pm 19.91^{* * *}(5)$ & $212.00 \pm 16.73^{* * * *}(5)$ & $199.20 \pm 30.17^{* * *}(5)$ \\
\hline
\end{tabular}

${ }^{* * *} p<0.001$ VS Control, ${ }^{*} p<0.05$ VS DM- 0 , and $+p<0.05$ VS DM+I

\section{Reverse Transcriptase-Polymerase Chain Reaction (RT-PCR)}

The reverse transcriptase polymerase chain reactions (PCR) for caspase-3, IGF-1 and $\beta$-actin were performed using Thermal Cycler system (Select BioProduct, Taiwan), with the following primer pairs: caspase-3 forward : 5'-CGT ACA GGT TCA GCA TGG C-3', and reverse : 5'-CCG ACT TCC TGT ATG CTT ACT C-3' ;IGF-1 forward 5'-CGT ACC AAA ATG AGC GCA CC-3, and reverse 5'-TCC GGA ACG AAC ACT CAT CC-3; $\beta$-actin 1 forward: 5 '-ACA ACC TTC TTG CAG CTC CTC-3', and reverse 5'-AAT GCC GTG TTC AAT GGG GT-3'. Each Thermal Cycler PCR run consisted of 35 cycles with initial denaturation time of $2 \mathrm{~min}$ at $94^{\circ} \mathrm{C}$. The cycling for all primers was set at: $94^{\circ} \mathrm{C}$ for $10 \mathrm{~s}, 60^{\circ} \mathrm{C}$ for $20 \mathrm{~s}$, $72^{\circ} \mathrm{C}$ for $48 \mathrm{~s}$. The last extension time was at $10 \mathrm{~min}$ at $72^{\circ} \mathrm{C}$. Agarose gel electrophoresis was used to confirm the specificity of the priming. RT-PCR products were visualized with UV light and quantified by densitometry analysis from ImageJ software. Caspase- 3 and IGF-1 were expressed relative to that of $\beta$-actin in the same samples.

\section{Statistical analysis}

Data presented in this paper are reported mean \pm standard deviation (SD). One-way analysis of variance (ANOVA) followed by LSD's multiple comparison test was performed for analyzing differences between treatment group. Statistical significance was considered for $p<0.05$.

\section{RESULTS AND DISCUSSION}

\section{Animal model-body weight and serum glucose}

Weight loss in the DM group compared to control group was significantly different (Table I). Weight loss is in line with the state of hyperglycemia experienced, relevant to research conducted by Gandhi et al., (2006). Giving insulin caused an increase in body weight compared to DM group without insulin. The cause of weight gain is because insulin has an anabolic effect on proteins (Dimitriadis et al., 2011). Wolfe (2000) states that protein synthesis is stimulated by insulin. Carver (2006) also explained that the effect of insulin on weight gain was due to the anabolic effect of protein in the muscles and lipogenesis. The insulininduced lipogenesis is caused by the transcription of the sterol regulatory element binding protein-1 (SREBP-1), which will cause lipogenic gene expression (Kersten, 2001).

The high blood glucose levels in the DM group who were given combined insulin and PRP therapy compared with the DM group given insulin without PRP, was due to the presence of glucose levels in PRP. It was found that there is the presence of glucose levels other than leukocytes. The mean and SD of the glucose levels were $18.5 \pm 2.73-23.6 \pm 1.36 \mathrm{mmol} / \mathrm{L}$ in the Fitzpatrick et al. (2017) study. The results of this glucose level were obtained using 4 different kits.

\section{Caspase-3 mRNA expression in testicular rats}

Caspase-3 mRNA expression in the DM group was higher than the control group but the significant value of 0.049 while very close to 0.05 was not significant (Figure 1), which indicates an additional need for STZ induction time. This study used 3 weeks 3 days from DM or 4 weeks for STZ induction, then added 2 weeks for insulin and PRP administration. The use of STZ induction time refers to a study conducted by Olchosky et al. (1991), which examined IGF-1 levels of 17-20 days (3 weeks) in DM rats. Whereas in other studies such as Sisman et al. (2014), it took 5 weeks after STZ administration to examine VEGF in the testes. On the other hand, Kianifard et al. (2012) needed 10 weeks to study damage of mitochondrial Sertoli cells and Leydig cells in DM testes. Kong et al. (2016) used a time of 2 months (8 weeks) during the STZ induction period to see the effect of therapy on testicular repair. 
A

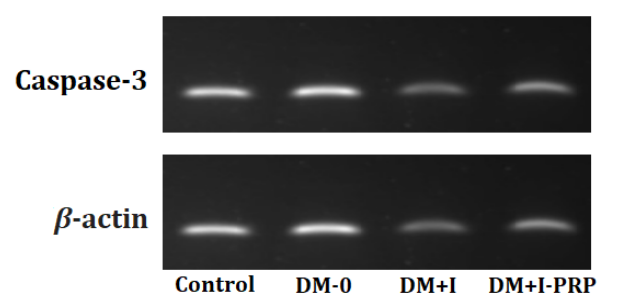

B

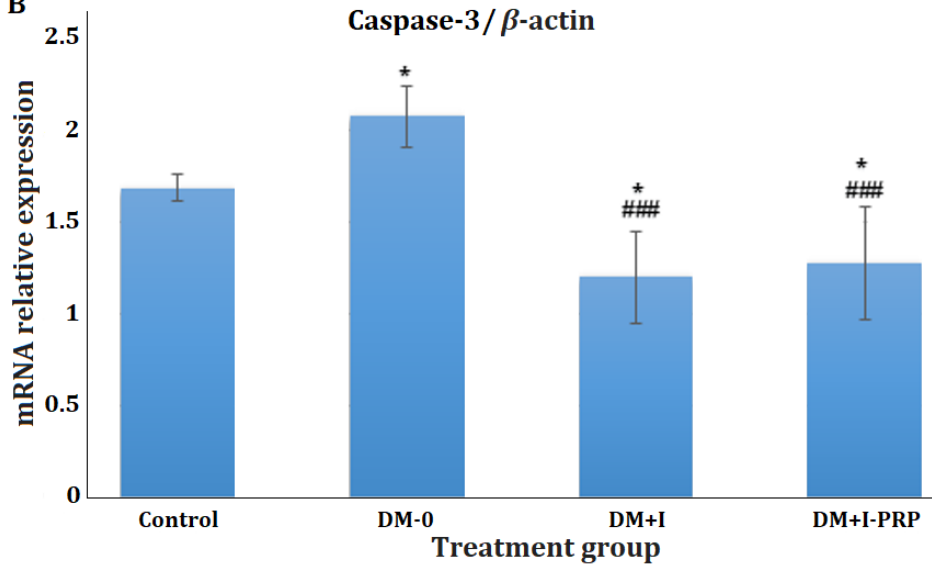

Figure 1.Caspase-3 / $\beta$-actin mRNA expression in rat testes after 2 weeks of insulin and PRP administration. (A) Representative figure of RT-PCR for caspase-3 and $\beta$-actin. (B) Densitometry analysis for caspase-3 mRNA expression in rat testes, measured as densitometry reading of PCR products normalized with housekeeping gene $\left(\beta\right.$-actin). Results are expressed as mean \pm SD. Significance is indicated by ${ }^{*}$ for $p<0.05$ compared to Control and $\# \# \#$ for $\mathrm{p}<0.001$ compared to DM-0.

A

IGF-1

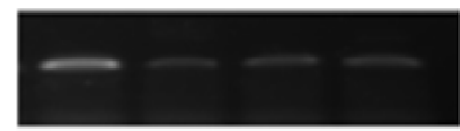

$\beta$-actin

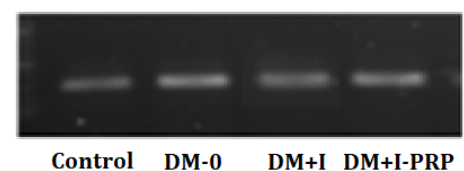

B

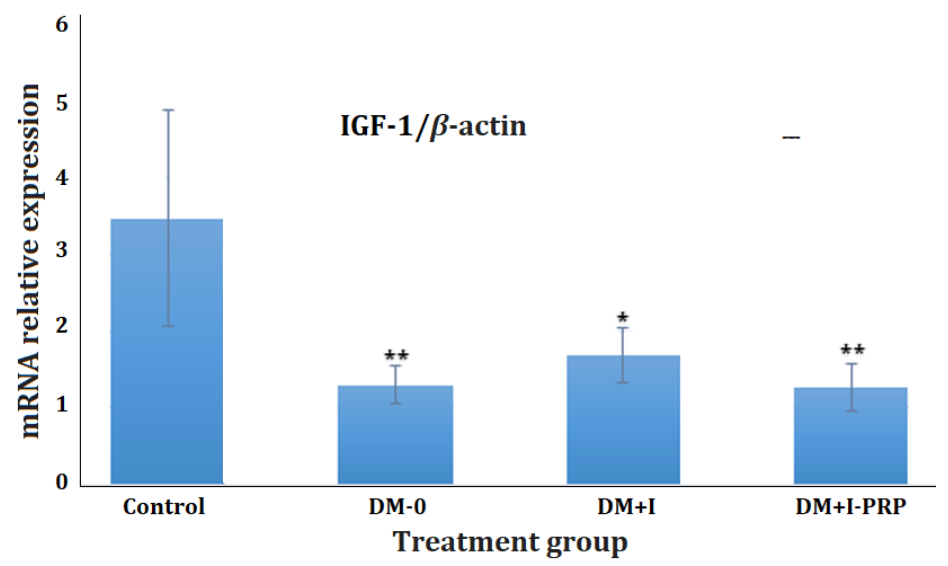

Figure 2. IGF-1 / $\beta$-actin mRNA expression in rat testes after 2 weeks of insulin and PRP administration. (A) Representative figure of RT-PCR for IGF-1 and $\beta$-actin. (B) Densitometry analysis for IGF-1 mRNA expression in rat testes, measured as densitometry reading of PCR products normalized with housekeeping gene ( $\beta$-actin). Results are expressed as mean \pm SD. Significance is indicated by ${ }^{*}$ for $p<0.05$ and ${ }^{* *}$ for $p<$ 0.01 compared to Control.

Increased caspase-3 mRNA expression in the control group was because physiological apoptosis occurs in the process of spermatogenesis (Said, 2004). The presence of caspase-3 in the control group was also in line with the study of Sekerci et al. (2017), that involved giving PRP in the testis which experienced torsion. Morsy et al. (2014) also found the same result, finding the higher presence of caspase-3 expression in the control group compared to the DM group.
The high caspase- 3 mRNA expression in the control group and DM group without insulin compared to the insulin therapy groups, both with PRP and without PRP, showed that the addition of insulin can reduce caspase- 3 in the testis. Insulin activates phosphoinositol 3 kinase (PI3K) which is anti-apoptotic and thus decreases apoptosis lower than those not given insulin, according to the result obtained through in vitro research (Kang et al., 2003). A longer study time is needed so that 
caspase-3 derived is caspase-3. A longer time is also required for STZ induction to ensure a decrease in caspase-3 mRNA expression from pathological apoptosis due to DM.

Caspase-3 mRNA expression on insulin administration without PRP was lower than the administration of insulin combined with PRP, but this difference was not significant. The cause of higher caspase- 3 in the DM+I-PRP group than in the DM+I group was because of the presence of leukocytes contained in PRP. Pavlovic et al. (2016) stated that the presence of leukocytes can trigger ROS. However, Wu et al. (2016) stated that leukocytes can influence the therapy of PRP administration if the leukocyte level in PRP reaches more than 21,000/mL. Devereaux et al. (2018) states that the presence of leukocytes does not affect the success of PRP therapy. The existence of this controversy requires additional research to determine the safety of the use of PRP if accompanied by leukocytes (Martínez-Zapata et al., 2009).

\section{IGF-1 mRNA expression in testicular rats}

This study obtained IGF-1 mRNA expression in the testis for all DM groups significantly lower than the control group (Figure 2). The group given insulin had an increase in IGF-1 mRNA expression compared with the DM group without insulin therapy, but it was not significant. Addition of PRP to the testis with a level of $0.1 \mathrm{~mL}$ with a frequency of 3 times in 2 weeks did not increase IGF-1 mRNA expression. This is different from the administration of PRP in fractured rats (Lyras et al., 2010) and in humans who are athletes who need recovery (Wasterlain et al., 2013). Lyras et al. (2010) conducted a gradual examination to assess the increase in IGF-1 in the endotendon, so that it could be assessed to increase IGF-1 levels. Wasterlain et al. (2013) also did something similar, namely when adding the existence of the examination stage, it was found that IGF-1 increased initially but there was no further improvement.

The results of this study indicate that PRP in a subscrotal injection does not increase IGF-1 mRNA expression in the diabetic rat testis. It could even be that PRP administration can block the production of IGF-1 in the testes because of negative feedback in the hypothalamus which reduces growth hormone-releasing hormone (GHRH) levels, then the reduced GHRH level will affect the anterior pituitary to produce GH (Barrett, 2017). The presence of GH is important in the production of IGF-1 (Nambam and Schatz, 2018). The presence of GH also determines the success of stem cells (Chemaitilly and Sklar, 2007). DM conditions will certainly reduce $\mathrm{GH}$ due to disorders of the hypothalamus (Bonert and Melmed, 2017).

This study indicates that the addition of PRP did not affect the improvement compared to administration of insulin without PRP. The results of the conclusions are the same as Levy et al. (2018), who used PRP in patients who had problems with the tendon. But the results of this study are different from studies using PRP to repair damage to the ovaries and testes. Studies by Bakacak et al. (2015) and Sekerci et al. (2017) revealed that there was improvement in the provision of PRP.

The difference between this research and the research that states the success of PRP is the way of administering PRP, namely intraperitoneal injection in ovarian torsion (Bakacak et al., 2015) and intratesticular in testicular torsion (Sekerci et al., 2017). The method done by intratesticular injection is prone to autoimmune sperm because it damages the blood testis barrier. Damage to the blood testis barrier will conflict with the goal of repairing the testis, namely maintaining male fertility (Bronson, 1999; Koksal et al., 2007).

\section{CONCLUSION}

There was no difference in caspase- 3 and IGF-1 mRNA expression in the diabetic rat testis given insulin and PRP compared to without PRP.

\section{ACKNOWLEDGEMENTS}

Special appreciation goes to Nur Arfian (Department of Anatomy, Faculty of Medicine, Public Health and Nursing, Universitas Gadjah Mada, Yogyakarta, Indonesia), for his insights on this study. The authors express thanks to Wiwit Ananda Wahyu Setyaningsih, Yuyun Nailufar and staff of The Anatomy Laboratory Faculty of Medicine, Public Health and Nursing of Universitas Gadjah Mada who have assisted and allowed the use of methods in this study: This study was supported by a grant (PRJ/4717/LPDP.3/2016) obtained from Beasiswa Unggulan Dosen Indonesia dalam Negeri (BUDI-DN) and by Lembaga Pengelola Dana Pendidikan (LPDP).

\section{REFERENCES}

Bakacak M., Bostanci MS., İnanc F., Yaylali A., Serin S., Attar R.., et al., 2015. Protective effect of platelet rich plasma on experimental 
ischemia/reperfusion injury in rat ovary. Gynecol. Obstet. Invest. 81: 225-231.

Barrett EJ., 2017. Endocrine regulation of growth and body mass. In: Boron WF., Boulpaep EL (Ed.): Medical Physiology. 3rd ed. Elsevier, Philadelphia. pp. 990-1005

Bonert VS. and Melmed S. (Ed.), 2017. Growth hormone. The Pituitary. 4th ed. Elsevier, London. pp. 85-127

Bronson RA., 1999. Antisperm antibodies: A critical evaluation and clinical guidelines. J. Reprod. Immunol. 45: 159-183.

Carver C., 2006. Insulin treatment and the problem of weight gain in type 2 diabetes. Diabetes Educ. 32: 910-917.

Castilla-Cortázar I., Gago A., Muñoz Ú., ÁvilaGallego E., Guerra-Menéndez L., Sádaba MC., García-Magariño M., et al., 2015. Mechanisms underlying testicular damage and dysfunction in mice with partial IGF-1 deficiency and the effectiveness of IGF-1 replacement therapy. Urology 86: 12411250.

Chemaitilly W. and Sklar CA., 2007. Endocrine complications of hematopoietic stem cell transplantation. Endocrinol. Metab. Clin. North Am. 36: 983-998.

Devereaux J., Nurgali K., Kiatos D., Sakkal S. and Apostolopoulos V., 2018. Effects of plateletrich plasma and platelet-poor plasma on human dermal fibroblasts. Maturitas 117: 34-44.

Dhillon RS., Schwarz EM. and Maloney MD., 2012. Platelet-rich plasma therapy - future or trend? Arthritis Res. Ther. 14: 219-229.

Dimitriadis G., Mitrou P., Lambadiari V., Maratou E., and Raptis SA., 2011. Insulin effects in muscle and adipose tissue. Diabetes Res. Clin. Pract. 93: S52-S59.

El-Sharkawy H., Kantarci A., Deady J., Hasturk H., Liu H., Alshahat M., et al., 2007. Platelet-rich plasma: Growth factors and pro- and antiInflammatory properties. J. Periodontol. 78: 661-669.

Fitzpatrick J., Bulsara MK., McCrory PR. and Richardson MD., Zheng MH., 2017. Analysis of platelet-rich plasma Extraction. Orthop. J. Sport. Med. 5: 2325967116675272.

Gandhi A., Doumas C., O'Connor JP., Parsons JR. and Lin SS., 2006. The effects of local platelet rich plasma delivery on diabetic fracture healing. Bone. 38: 540-546.

Kang S., Song J., Kang H., Kim S., Lee Y. and Park D., 2003. Insulin can block apoptosis by decreasing oxidative stress via phosphatidylinositol 3-kinase- and extracellular signal-regulated protein kinase-dependent signaling pathways in HepG2 cells. Eur. J. Endocrinol. 148: 147155.

Kersten S., 2001. Mechanisms of nutritional and hormonal regulation of lipogenesis. EMBO Report. 2: 282-286.

Kianifard D., Sadrkhanlou RA. and Hasanzadeh S., 2012. The ultrastructural changes of the Sertoli and Leydig cells following streptozotocin induced diabetes. Iran. J. Basic Med. Sci. 15: 623-635.

Koksal IT., Ishak Y., Usta M., Danisman A., Guntekin E., Bassorgun IC., et al., 2007. Varicoceleinduced testicular dysfunction may be associated with disruption of blood-testis barrier. Arch. Androl. 53: 43-48.

Kong W-Y., Tong L-Q., Zhang H-J., Cao Y-G. and Wang G-C., Zhu J-Z., et al., 2016. The calciumsensing receptor participates in testicular damage in streptozotocin-induced diabetic rats. Asian J. Androl. 18: 803-808.

Levy GM., Lucas P. and Hope N., 2018. Efficacy of a platelet-rich plasma injection for the treatment of proximal hamstring tendinopathy: A pilot study. J. Sci. Med. Sport. 22: 247-252.

Lyras DN., Kazakos K., Agrogiannis G., Verettas D., Kokka A., Kiziridis G., et al., 2010. Experimental study of tendon healing early phase: Is IGF-1 expression influenced by platelet rich plasma gel? Orthop. Traumatol. Surg. Res. 96: 381-387.

Martínez-Zapata MJ., Martí-Carvajal A., Solà I., Bolibar I., Ángel Expósito J., Rodriguez L., et al., 2009. Efficacy and safety of the use of autologous plasma rich in platelets for tissue regeneration: A systematic review. Transfusion. 49: 44-56.

Morsy M., Ramzy M., El-Sheikh AK., Kamel M. and Abdelwahab S., 2014. Mechanism of testicular protection of carvedilol in streptozotocin-induced diabetic rats. Indian J. Pharmacol. 46: 161-165.

Nambam B., Schatz D., 2018. Growth hormone and insulin-like growth factor-I axis in type 1 diabetes. Growth Horm. IGF Res. 38: 49-52.

Olchosky D., Bruno JF., Gelato MC., Song J., and Berelowitz M., 1991. Pituitary insulin-like growth factor-I content and gene expression in the streptozotocin-diabetic rat: Evidence for tissue-specific regulation*. 
Endocrinology 128: 923-928.

Ozkurkcugil C., Yardimoglu M., Dalcik H., Erdogan S. and Gokalp A., 2004. Effect of insulin-like growth factor-1 on apoptosis of rat testicular germ cells induced by testicular torsion. BJU Int. 93: 1094-1097.

Puche JE. and Castilla-Cortázar I., 2012. Human conditions of insulin-like growth factor-I (IGF-I) deficiency. J. Transl. Med. 10: 224.

Said TM., 2004. Role of caspases in male infertility. Hum. Reprod. Update. 10: 39-51.

Sekerci CA., Tanidir Y., Sener TE., Sener G., Cevik O., Yarat A., et al., 2017. Effects of platelet-rich plasma against experimental ischemia/reperfusion injury in rat testis. J. Pediatr. Urol. 13: 317.e1-317.e9.

Shi G., Li Z-M., Zheng J., Chen J., Han X., Wu J., et al., 2017. Diabetes associated with male reproductive system damages: Onset of presentation, pathophysiological mechanisms and drug intervention. Biomed. Pharmacother. 90: 562-574.

Shi G-J., Zheng J., Wu J., Qiao H-Q., Chang Q., Niu Y., et al., 2017. Beneficial effects of Lycium barbarum polysaccharide on spermatogenesis by improving antioxidant activity and inhibiting apoptosis in streptozotocin-induced diabetic male mice. Food Funct. 8: 1215-1226.

Sisman AR., Kiray M., Camsari UM., Evren M., Ates M., Baykara B., et al., 2014. Potential novel biomarkers for diabetic testicular damage in streptozotocin-induced diabetic rats: Nerve growth factor beta and vascular endothelial growth factor. Dis. Markers: 2014: 108106.

Wang G. and Hardy MP., 2004. Development of Leydig cells in the insulin-like growth factor-I (IGF-I) knockout mouse: Effects of IGF-I replacement and gonadotropic stimulation. Biol. Reprod. 70: 632-639.

Wasterlain AS., Braun HJ., Harris AHS., Kim H. and Dragoo JL., 2013. The systemic effects of platelet-rich plasma injection. Am. J. Sports Med. 41: 186-193.

Wolfe RR., 2000. Effects of insulin on muscle tissue. Curr. Opin. Clin. Nutr. Metab. Care. 3: 67-71.

Wu PIK., Diaz R. and Borg-Stein J., 2016. Plateletrich plasma. Phys. Med. Rehabil. Clin. N. Am. 27: 825-853.

Yoon MJ. and Roser JF., 2010. Insulin-like growth factor-I (IGF-I) protects cultured equine Leydig cells from undergoing apoptosis. Anim. Reprod. Sci. 122: 353-358. 